\title{
A Failure Mechanism Study of Boiler Water-Wall Tube using Numerical and Experimental Analysis
}

\author{
Saeed Asiri
}

\begin{abstract}
The aim of this study is to investigate the boiler tube failure mechanism using finite element analysis and experimental Analysis. The numerical software used is ANSYS steady-state thermal and static structural analysis. The independent variable for the analysis is temperature from flue gas and wall thickness of boiler tube. The scope of the study is to determine the temperature distribution, von mises stress, deformation and safety factor by implemented design of experiment. The material of boiler tube sketch in two dimensional for simulation is SA210 Grade C. this is standard requirements for the boiler made of seamless medium-carbon steel with superheater tubes according to ASTM. From the result and discussion, the potential of failure mechanism will determine upon independent variables. In addition, hoop stress or circumference stress will help to support the statement of failure of boiler tube.
\end{abstract}

Keyword: Thermal stress, static structural, temperature distribution, stress distribution, safety factor

\section{INTRODUCTION}

Boiler classification can be divided based on fuel type, application, firing method, the pressure of steam and so on. There are 2 types of boilers, fire tube that flue gas flows through the tubes and water tube that water or steam or both flows through tubes. In this paper, the water tube is the selected for the study. The water tube boiler consists of many coils, burners and drums. The coils divided into 4 groups which water wall tube, superheat, reheat and economizer. These group designed to specific function and operating condition. The boiler water tube is mainly used to absorb the radiation heat generated by flame and high temperature flowing gas in the furnace and has a function of cooling and protecting the furnace wall [1]. Failure of water wall tube is the main reason of boiler shutdown. Recent investigation and study have been concerned with report of failure cases in power plant associated with high temperature and corrosion factors. Overheating is another main reason for premature rupture of reheater and superheater tubes [4].

Manuscript received on August 14, 2021.

Revised Manuscript received on August 21, 2021.

Manuscript published on August 30, 2021.

* Correspondence Author

Dr. Saeed Asiri*, Associate Professor, Department of Mechanical Engineering, Engineering College, King Abdulaziz University, Saudi Arabia.

(C) The Authors. Published by Blue Eyes Intelligence Engineering and Sciences Publication (BEIESP). This is an open access article under the CC BY-NC-ND license (http://creativecommons.org/licenses/by-nc-nd/4.0/)
Therefore, the damage due to high temperature can be considered as the major boiler tube failure mechanism which can happen in varies approaches like oxidation, creep, microstructural changes because of thermal fatigue, low cycle fatigue, or combination of them in addition to overheating or interaction with the environment. The objective of this study is to discuss the failure in boiler tube in the steam power plant. This phenomenon can reduce the availability of plant around $20 \%$. The tube material is SA210 C-Grade. The tube diameter is $65 \mathrm{~mm}$ with various of thickness and temperature. Therefore thermal-steady state and static structural are the finite element analysis element used in Ansys. Implementation of design of experiment (DOE) in order to analysis result systematically. The design of experiment will implement in order to determine the temperature distribution, stress, deformation and safety factor by combination of thickness and temperature. Most of recent investigation, the tube boiler failure due temperature or hoop stress that over the allowable stress of the material. The surface of tube that exposed to the flue gas or fly-ash was tendency to wall thinning due to erosion [12]. Therefore, the scope of this study is focus on the surface of tube that facing or absorb the higher temperature. A 2D mathematical model of the tubes represent boiler tube is proposed to simulate thermal, stress, deformation and safety factor using the finite element analysis software Ansys.

\section{METHODOLOGY}

\subsection{Data Collection}

The design data collected from a power plant located in Saudi Arabia. The boiler was designed to carry 390MW load and supply the steam turbine with steam in different temperature and pressure (high pressure turbine $560^{\circ} \mathrm{C}$ and 160 Bar, intermediate turbine $360^{\circ} \mathrm{C}$ and 160 Bar and lowpressure turbine supply directly from IP section). Table I below shows the design data.

Table I: Design data

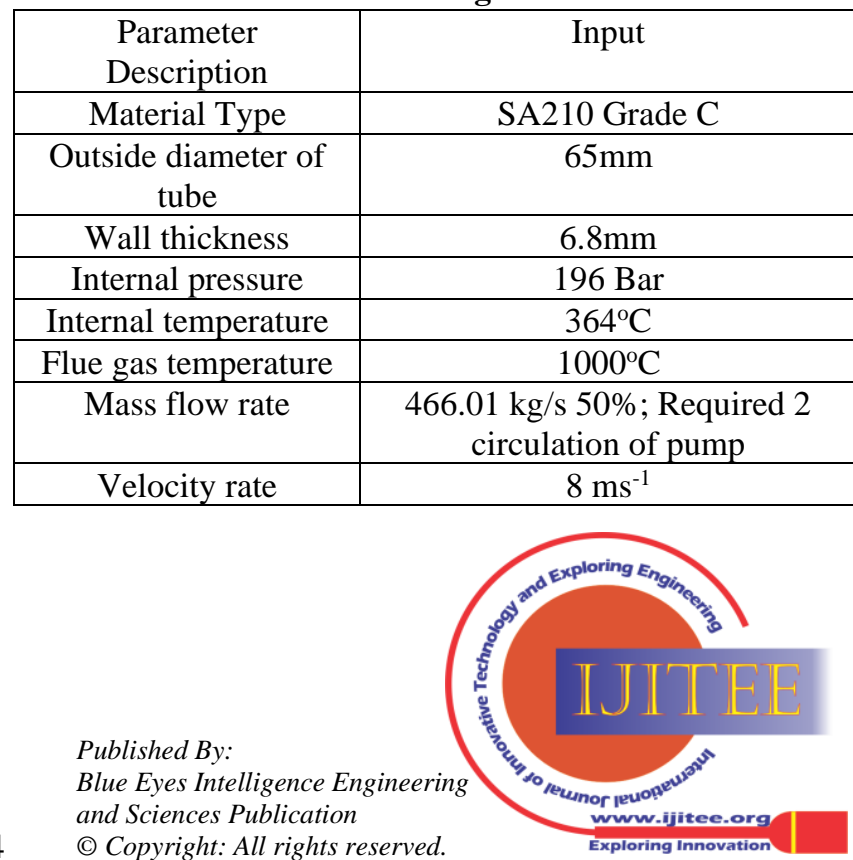




\subsection{Geometry Model}

The boiler tube sketch in Ansys Design Modeller in a 2D as shown in Figure 1. Due to design of experiment methodology, 3 sets of sketch design to represent $8 \mathrm{~mm}$, $5 \mathrm{~mm}$ and $2 \mathrm{~mm}$ wall thickness with same outside diameter and constant finned dimension.
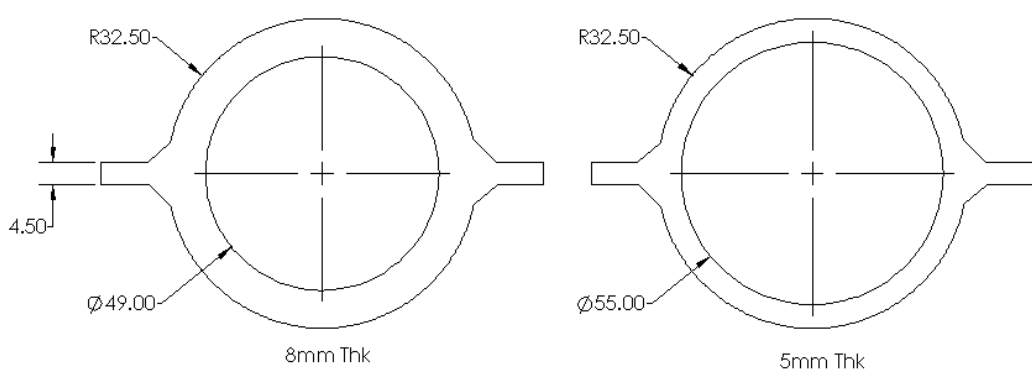

Fig. 1: Geometry model

\subsection{Numerical Method}

Numerical simulation has been performed using ANSYS to study the stress, deformation, safety factor due to applied variation variables of thermal and wall thickness of boiler tube. The analysis system involved in this study is steadystate thermal and static structural. At first steady-state thermal shall simulate and imported into static structural analysis in order to run the FEA based on the temperature given. Mesh convergence study shall simulate in order to define the accurate grid size for this study.

\subsection{Boundary Condition}

As shows in Figure 2, fixed support is applied on the edge of finned (both) tube. The tube is the section for this investigation for failure which is the wall thickness. While internal pressure and convection heat is applied inside diameter of tube which $19.6 \mathrm{MPa}$ and $364^{\circ} \mathrm{C}$. Variable's radiation heat of flue gas (fireside) is applied outside diameter of tube which $800^{\circ} \mathrm{C}, 1000^{\circ} \mathrm{C}$ and $1200^{\circ} \mathrm{C}$.

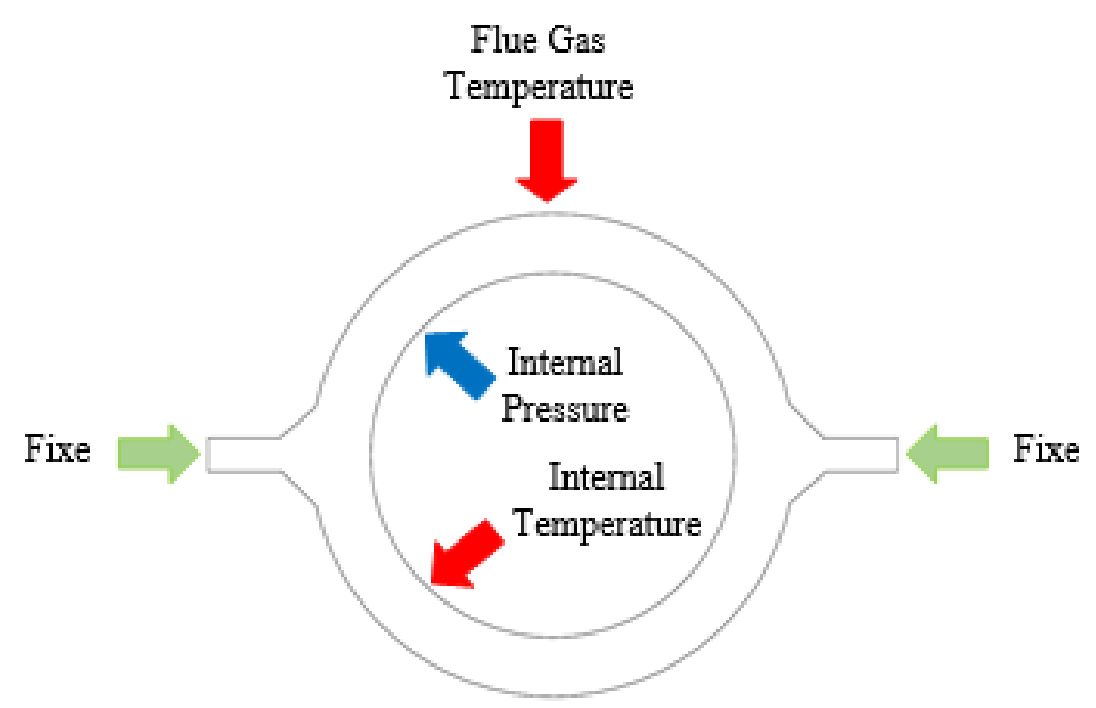

Fig. 2: Thermal Steady-State and Static Structural boundary condition

Table II: Mechanical properties of SA210 Grade C, ASTM

\begin{tabular}{|c|c|}
\hline Min Strength in MPa [ksi] & Grade C \\
\hline Tensile & $485[70]$ \\
\hline Yield & $275[40]$ \\
\hline
\end{tabular}

Refer to Figure 3, the stress significantly reduces due to temperature increased particularly for maximum allowable stress and tensile stress. However, yield stress gradually decreased. In this study, the temperature is the main input in thermal-steady state study.

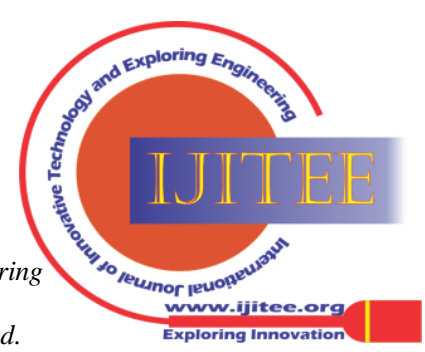




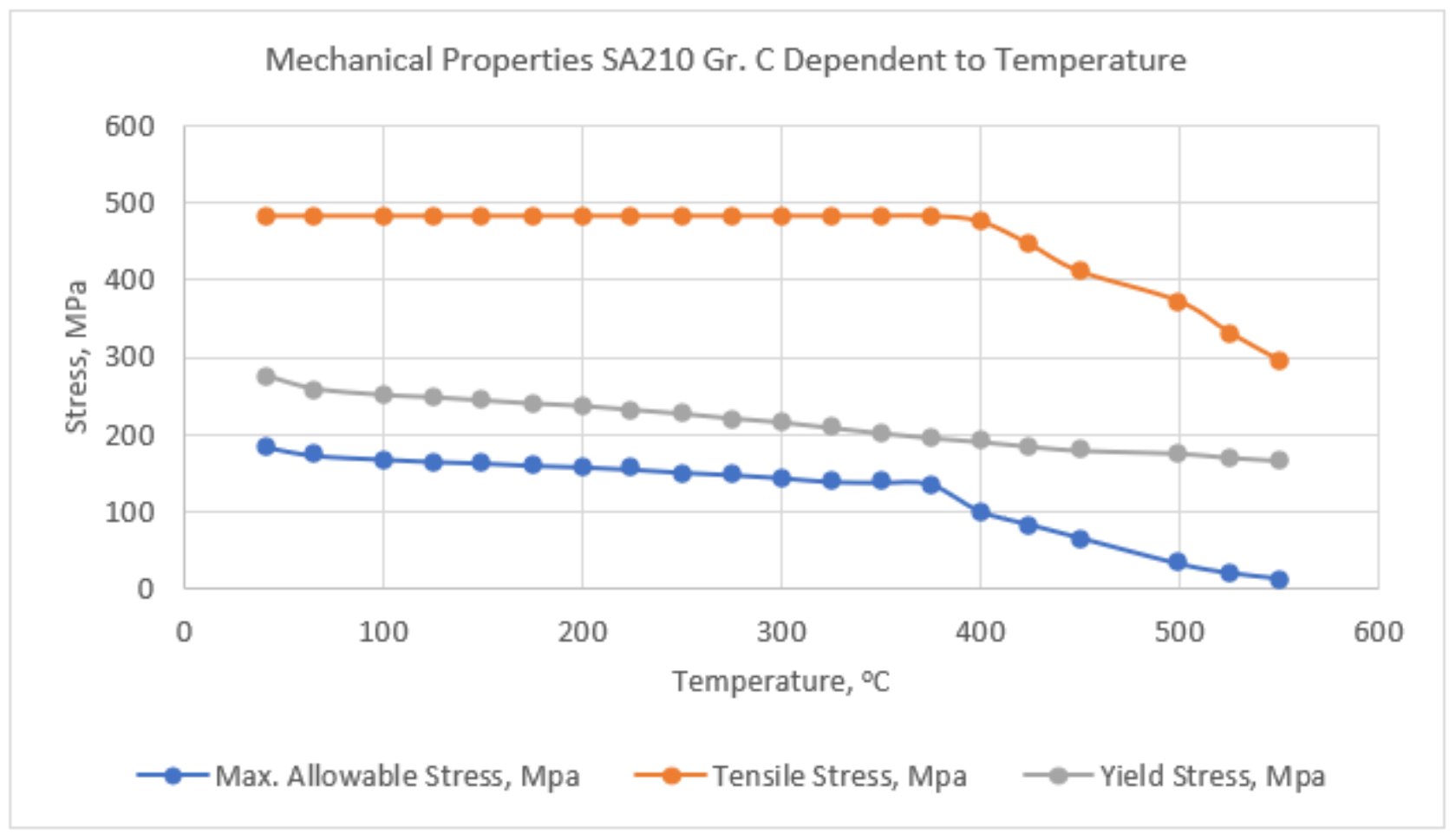

Fig. 3: Mechanical properties SA210 Grade C dependent to temperature

\subsection{Design of Experiment}

Refer to Table 3, 9 sets of simulation will run dependent to thickness of tube and temperature. From this study, comparison of data or result will be achieved in order to determine the mechanism of the failure for the boiler tube.

Table III: Experimental design point

\begin{tabular}{|c|c|c|}
\hline Design Point Number & Thickness, $\mathrm{mm}$ & Tube Maximum Temperature, ${ }^{\circ} \mathrm{C}$ \\
\hline 1 & 2 & 1200 \\
\hline 2 & 2 & 8000 \\
\hline 3 & 2 & 1200 \\
\hline 4 & 5 & 1000 \\
\hline 5 & 5 & 800 \\
\hline 6 & 5 & 1200 \\
\hline 7 & 2 & 1000 \\
\hline 8 & 2 & 800 \\
\hline 9 & 2 & \\
\hline
\end{tabular}

\section{VERIFICATION AND VALIDATION}

\subsection{Mesh Convergence}

The mesh convergence study has been made with 6 grid system. to determine the accuracy for the investigation. A sets of grid number set up in face mesh in order to compare the stress result at $\mathrm{y}$-axis, $32.5 \mathrm{~mm}$ of upper part boiler tube $8 \mathrm{~mm}$ with $800^{\circ} \mathrm{C}$ flue gas temperature. Thermal steady-state and static structural simulated for 6 grid sizes separately and plot the graph as shown in Figure 4. The results of Equivalent Von Mises Stress is the value to compared among the grid size in determining the constant result or saturation of elements. Table 4 shows the grid arrangement, mesh and Equivalent Von Mises Stress result. The results are plotted as per shown in Figure 4, indicates that grid 1, 2 and 3 shows a gap stress to grid size number 4 . While, grid number 4 slightly indicates very low different in stress to number 5 . However, the computational time for grid number 5 is longer than number 4 . To meet the efficiency of computational study, grid size $0.7 \mathrm{~mm}$ is selected for this research. The selected grid size shall apply to all tube thickness. The computer used to run the mesh convergence study is DELL Precision 3551, Intel ${ }^{\circledR}$ Core $^{\mathrm{TM}}$ i7-10750 CPU@2.60Hz 2.59 GHz, RAM 32.0 GB.

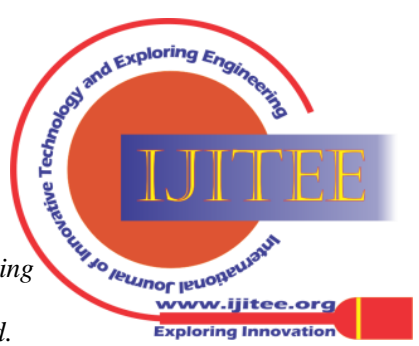




\section{Mesh Convergence}

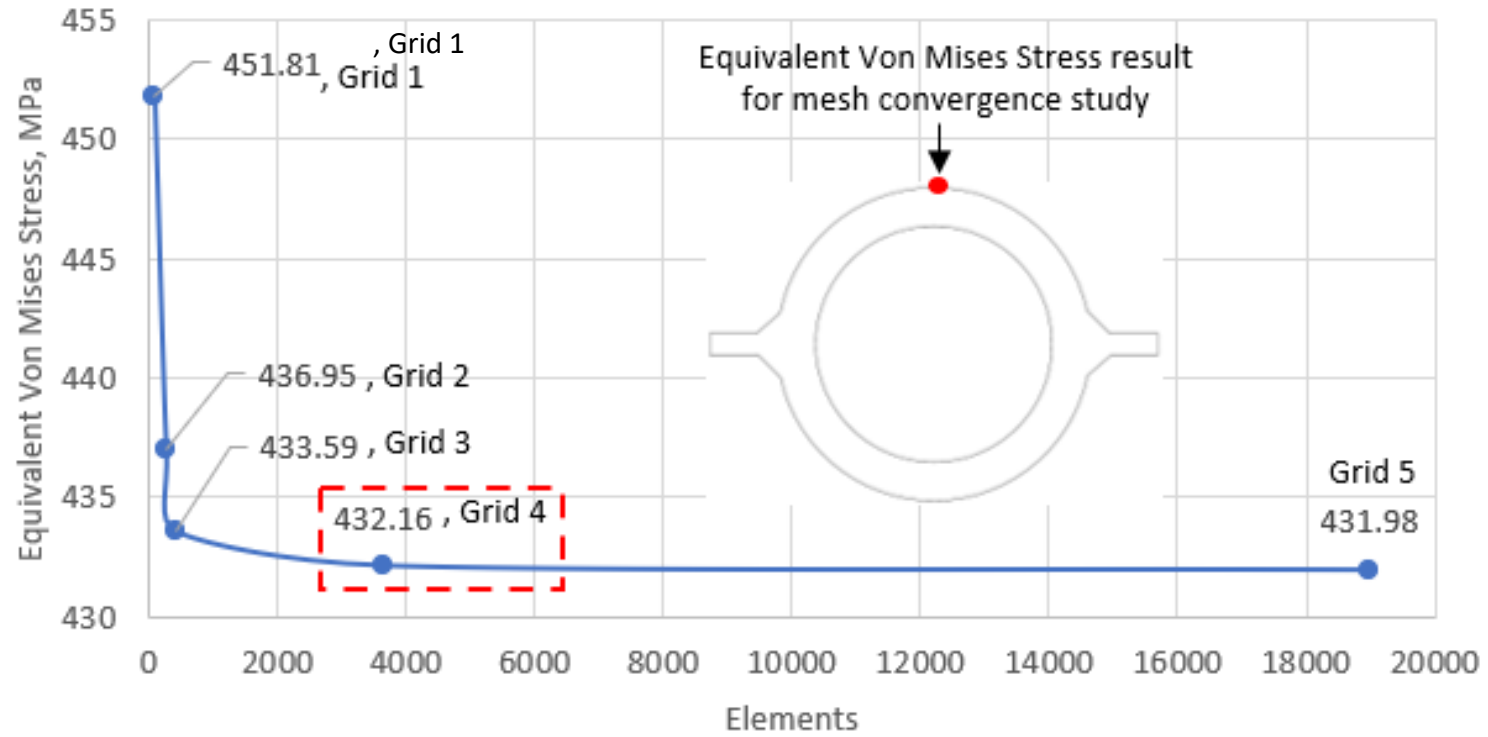

Fig. 4: Mesh convergence study chart

Table IV: Mesh convergence study results

\begin{tabular}{|c|c|c|c|c|}
\hline Grid Number & Grid Size, $\mathrm{mm}$ & Nodes & Elements & Stress, MPa \\
\hline 1 & 4.953 & 314 & 80 & 451.81 \\
\hline 2 & 2.5 & 939 & 261 & 436.95 \\
\hline 3 & 2 & 1,418 & 406 & 433.59 \\
\hline 4 & 0.7 & 11,491 & 3,645 & 432.16 \\
\hline 5 & 0.3 & 58,247 & 18,985 & 431.98 \\
\hline 6 & 0.1 & \multicolumn{3}{|c}{ Error!! } \\
\hline
\end{tabular}

\section{RESULT AND DISCUSSION}

\subsection{Mesh Model}

The grid size selected after considering the mesh convergence study which $0.7 \mathrm{~mm}$, as shown in Table 5 is the nodes and elements number for respective tube of boiler. The numbers of nodes and elements is depending on the external area of tube cross-section.
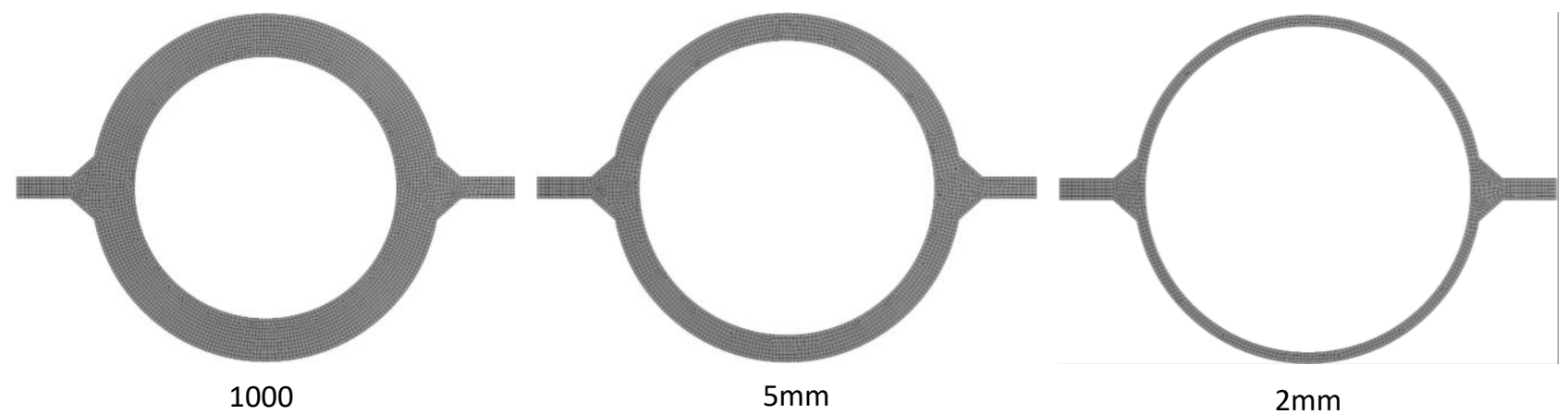

Fig. 5: Mesh model

Table V: Nodes and elements number

\begin{tabular}{|c|c|c|}
\hline Tube Thickness & Nodes & Elements \\
\hline $8 \mathrm{~mm}$ & 11,491 & 3,645 \\
\hline $5 \mathrm{~mm}$ & 7,608 & 2,340 \\
\hline $2 \mathrm{~mm}$ & 4,069 & 1,151 \\
\hline
\end{tabular}

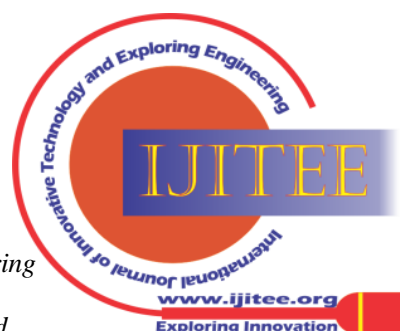




\subsection{Temperature Distribution}

The steady-state thermal analysis is used to understand and determine the boiler tube temperature based on the given temperature and wall thickness of boiler tube. The fireside surface. Figure 6 shows the temperature distribution radiant heat $800^{\circ} \mathrm{C}$ to the upper part of boiler tube. Refer to the graph on Figure 9, the temperature on the surface tube increase from $2 \mathrm{~mm}$ to $8 \mathrm{~mm}$. The maximum temperature recorded for $8 \mathrm{~mm}$ tube is $428.89^{\circ} \mathrm{C}$ compared to $5 \mathrm{~mm}$ at $425.31^{\circ} \mathrm{C}$ and $2 \mathrm{~mm}$ at $420.78^{\circ} \mathrm{C}$. Figure 7 shows the temperature distribution of radiant heat $1000^{\circ} \mathrm{C}$ to the upper part of boiler tube. Refer to the graph on Figure 9, the temperature on the surface increase from $2 \mathrm{~mm}$ to $8 \mathrm{~mm}$. The maximum temperature recorded for $8 \mathrm{~mm}$ tube is $502.57^{\circ} \mathrm{C}$ compared to $5 \mathrm{~mm}$ at $493.95^{\circ} \mathrm{C}$ and $2 \mathrm{~mm}$ at $484.35^{\circ} \mathrm{C}$. The average temperature gap between $800^{\circ} \mathrm{C}$ and $1000^{\circ} \mathrm{C}$ is higher which is $14 \%$. Figure 8 shows the temperature distribution of radiant heat $1200^{\circ} \mathrm{C}$ to the upper part of boiler tube. Refer to the graph on Figure 9, the temperature on the surface increase from $2 \mathrm{~mm}$ to $8 \mathrm{~mm}$. The maximum temperature recorded for $8 \mathrm{~mm}$ tube is $619.67^{\circ} \mathrm{C}$ compared to $5 \mathrm{~mm}$ at $603.77^{\circ} \mathrm{C}$ and $2 \mathrm{~mm}$ at $586.06^{\circ} \mathrm{C}$. the average temperature gap between $1000^{\circ} \mathrm{C}$ and $1200^{\circ} \mathrm{C}$ is getting higher which is $18 \%$. The whole of tubes shows a similarity in contour of temperature respect to the temperature given to the fireside of tube. The fireside or upper part boiler tube exposed with high temperature can lead to the oxidation, corrosion, and erosion. According to the recent investigation, short-term overheating was recognised as the main reason of boiler tube failure [12]. Refer to results of FEA, there are 2 major factors of increasing boiler tube stress which are thinning and high temperature. Tube skin temperature increasing due to short-term overheating increases the tube stress. Assume that, $8 \mathrm{~mm}$ and $5 \mathrm{~mm}$ is a uniform case and $2 \mathrm{~mm}$ is thinning or non-uniform tube cross-section, the stress $1 \mathrm{MPa}$ increased in between $300^{\circ} \mathrm{C}$ to $600^{\circ} \mathrm{C}$ and $2 \mathrm{MPa}$ stress increase for non-uniform tube cross-section. The upper part of tube boiler is the concern position to investigate. Local displacement in this area may tend to not safe according to the mechanical engineering design standard. Expected the higher temperature can caused higher deformation and stress. In addition, it will affect the factor of safety for the tubes.

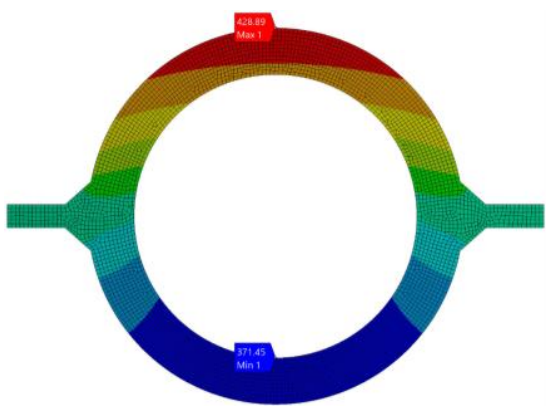

$8 \mathrm{~mm} @ 800^{\circ} \mathrm{C}$

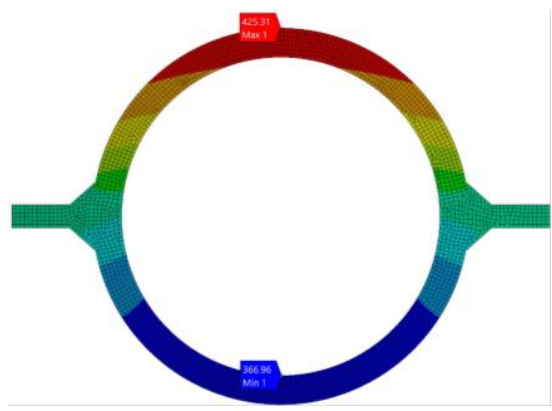

$5 \mathrm{~mm} @ 800^{\circ} \mathrm{C}$

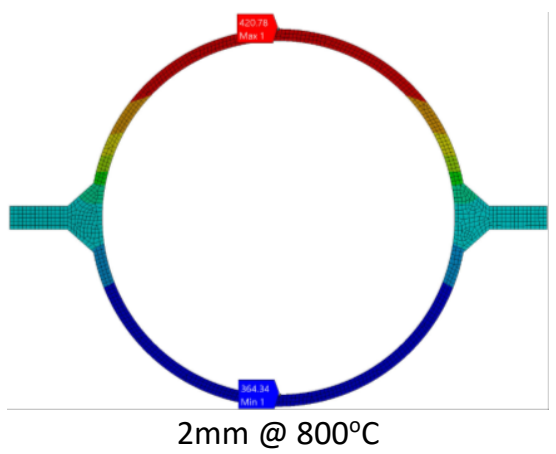

$2 \mathrm{~mm} @ 800^{\circ} \mathrm{C}$

Fig. 6: Temperature distribution at $800^{\circ} \mathrm{C}$

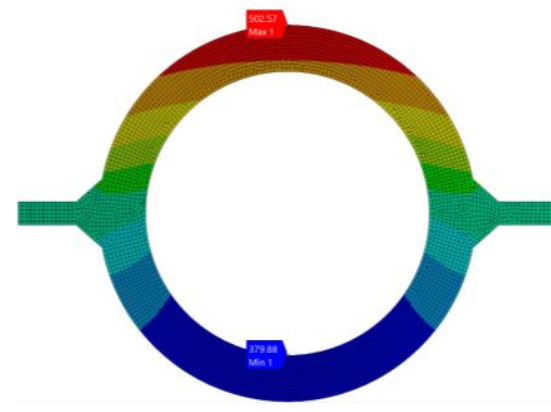

$8 \mathrm{~mm} @ 1000^{\circ} \mathrm{C}$

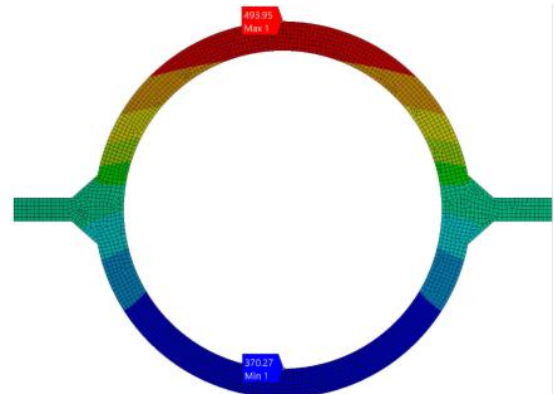

$5 \mathrm{~mm} @ 1000^{\circ} \mathrm{C}$

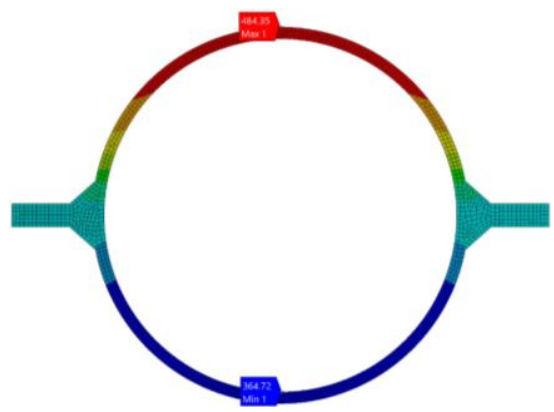

$2 \mathrm{~mm} @ 1000^{\circ} \mathrm{C}$

Fig. 7: Temperature distribution at $1000^{\circ} \mathrm{C}$ 


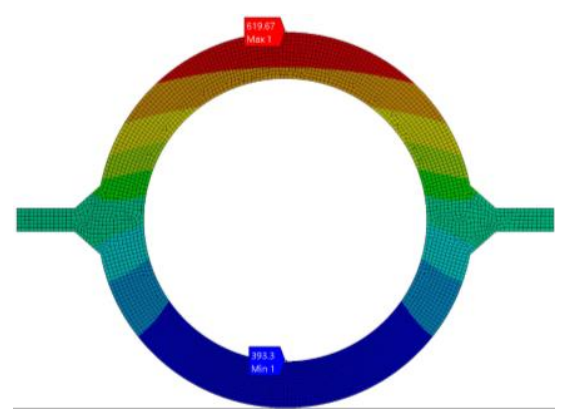

$8 \mathrm{~mm} @ 1200^{\circ} \mathrm{C}$

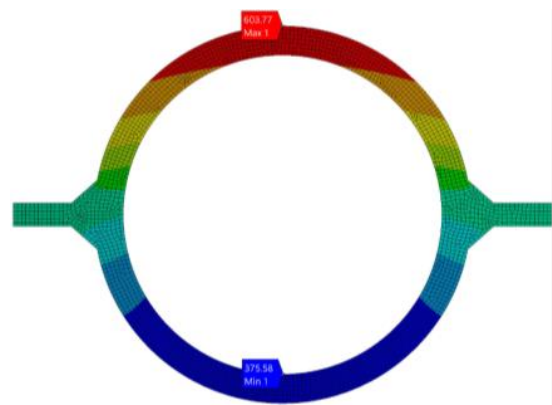

$5 \mathrm{~mm} @ 1200^{\circ} \mathrm{C}$

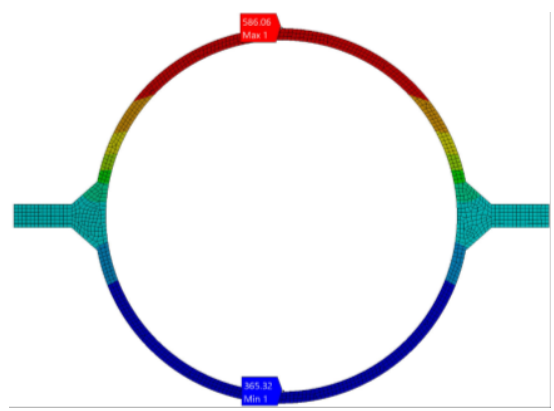

$2 \mathrm{~mm} @ 1200^{\circ} \mathrm{C}$

Fig. 8: Temperature distribution at $1200^{\circ} \mathrm{C}$

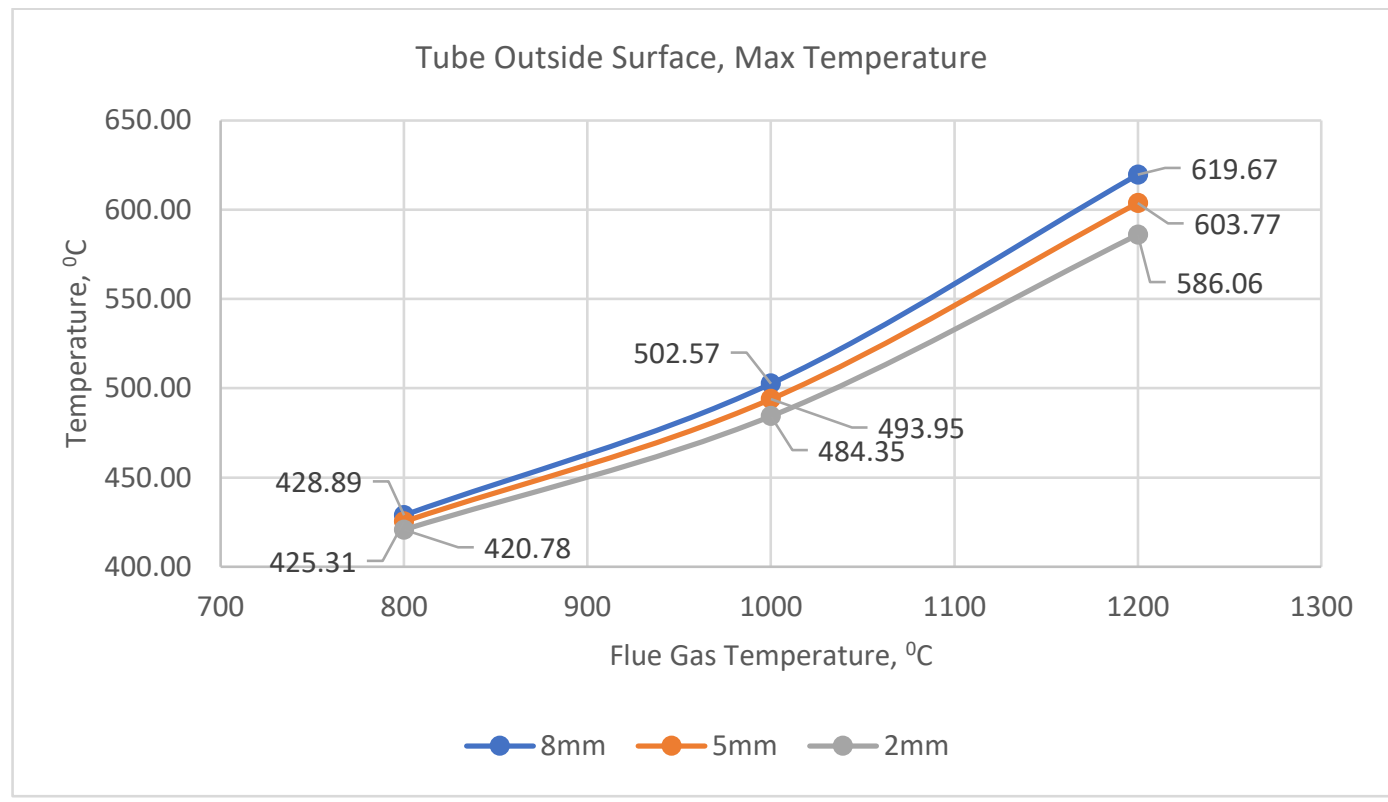

Fig. 9: Temperature on tube outside surface

\subsection{Equivalent Von Mises Stress}

The temperature solution in steady state thermal analysis imported into static structural analysis to study the reaction of the stress to the respective temperature. The internal pressure, 19.6MPa set up and pin the fixed point at the edge of finned tube to study the behaviour of stress on the upper side of tube. Figure 10 shows the stress distribution of tube boiler based on the $800^{\circ} \mathrm{C}$ flue gas temperature set up on the upper part of tube. The maximum stress at fireside of $8 \mathrm{~mm}$ tube which $432.16 \mathrm{MPa}$ but $2 \mathrm{~mm}$ shows a significant stress 420.34MPa. Due to very low thickness, the stress is distributed to the circumferential of tube.

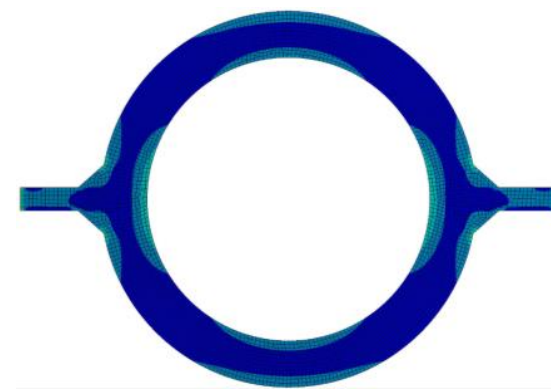

$8 \mathrm{~mm} @ 800^{\circ} \mathrm{C}$

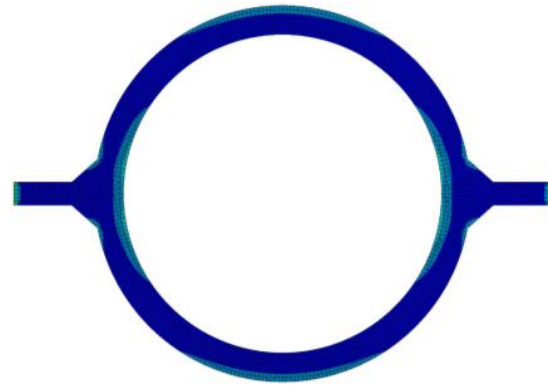

$5 \mathrm{~mm} @ 800^{\circ} \mathrm{C}$

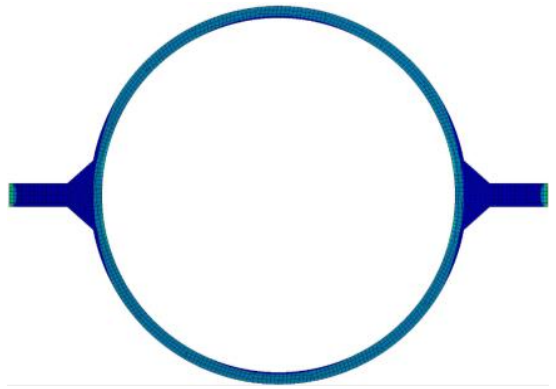

$2 \mathrm{~mm} @ 800^{\circ} \mathrm{C}$

Fig. 10: Von Mises Stress at $800^{\circ} \mathrm{C}$

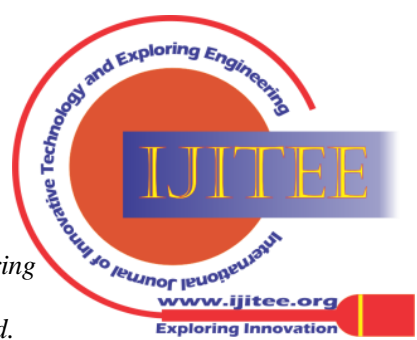


Figure 11 shows the stress distribution of tube boiler based on $1000^{\circ} \mathrm{C}$ flue gas temperature set up on the part of tube.
The maximum stress recorded at fireside is $8 \mathrm{~mm}$ tube which 466.37MPa and followed by $2 \mathrm{~mm}$ at $431.21 \mathrm{MPa}$. Wall thickness $2 \mathrm{~mm}$ tube shows lower stress at 402.3MPa.

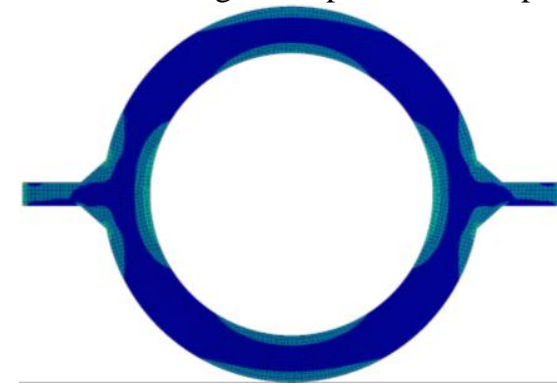

8mm@

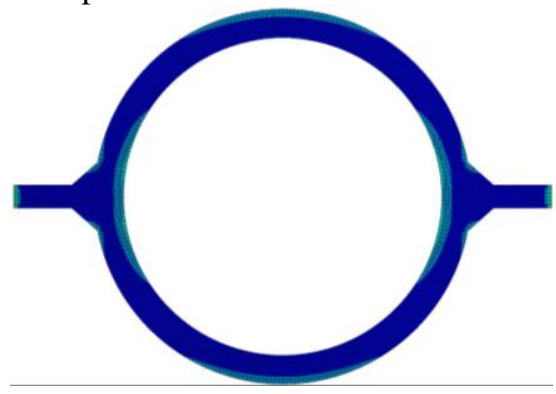

$5 \mathrm{~mm} @ 1000^{\circ} \mathrm{C}$

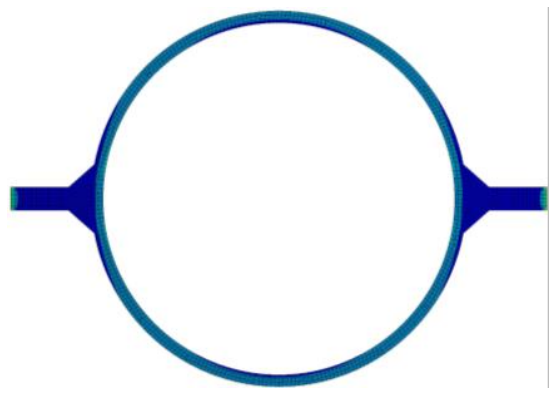

$2 \mathrm{~mm} @ 1000^{\circ} \mathrm{C}$

Fig. 11: Von Mises Stress at $1000^{\circ} \mathrm{C}$

Figure 12 shows the stress distribution of tube boiler based on $1200^{\circ} \mathrm{C}$ flue gas temperature set up on the upper part of tube. The maximum stress recorded on the surface of tube is $520.53 \mathrm{MPa}$ for $8 \mathrm{~mm}$ tube. It is followed by $2 \mathrm{~mm}$ tube at 448.6MPa. While $5 \mathrm{~mm}$ tube still show lower stress at 437.73MPa. The thermal effects on the internal convection and external radiation heat caused the increasing of stress at each of tubes. In addition the internal pressure caused compressive stress at the side of tube and tensile stress on upper and lower part of tube. Significantly, the tube wall thickness $8 \mathrm{~mm}$ and $5 \mathrm{~mm}$ show gradually increase stress when the flue gas temperature increases as shown in Figure 13 . However, the tube $2 \mathrm{~mm}$ indicate constant stress value.

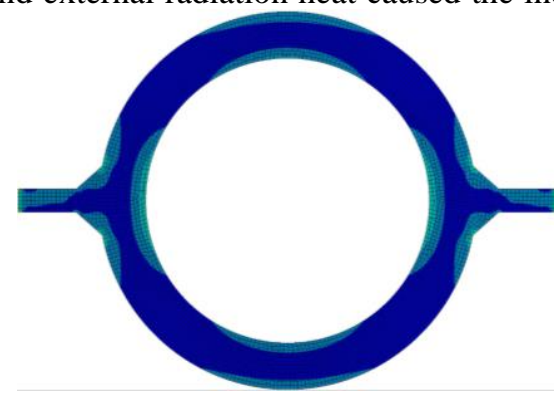

$8 \mathrm{~mm} @ 1200^{\circ} \mathrm{C}$

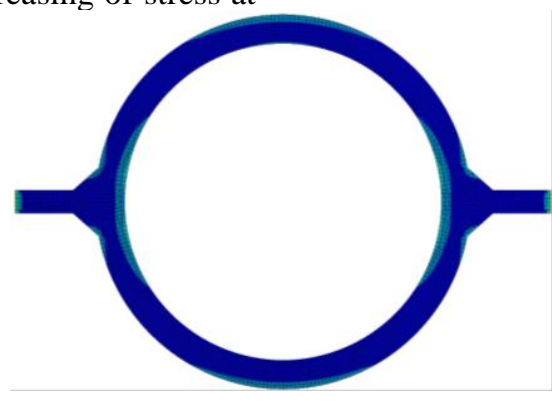

$5 \mathrm{~mm} @ 1200^{\circ} \mathrm{C}$

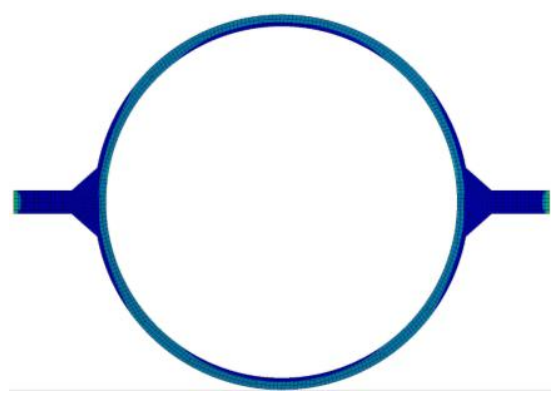

$2 \mathrm{~mm} @ 1200^{\circ} \mathrm{C}$

Fig. 12: Von Mises Stress at $1200^{\circ} \mathrm{C}$

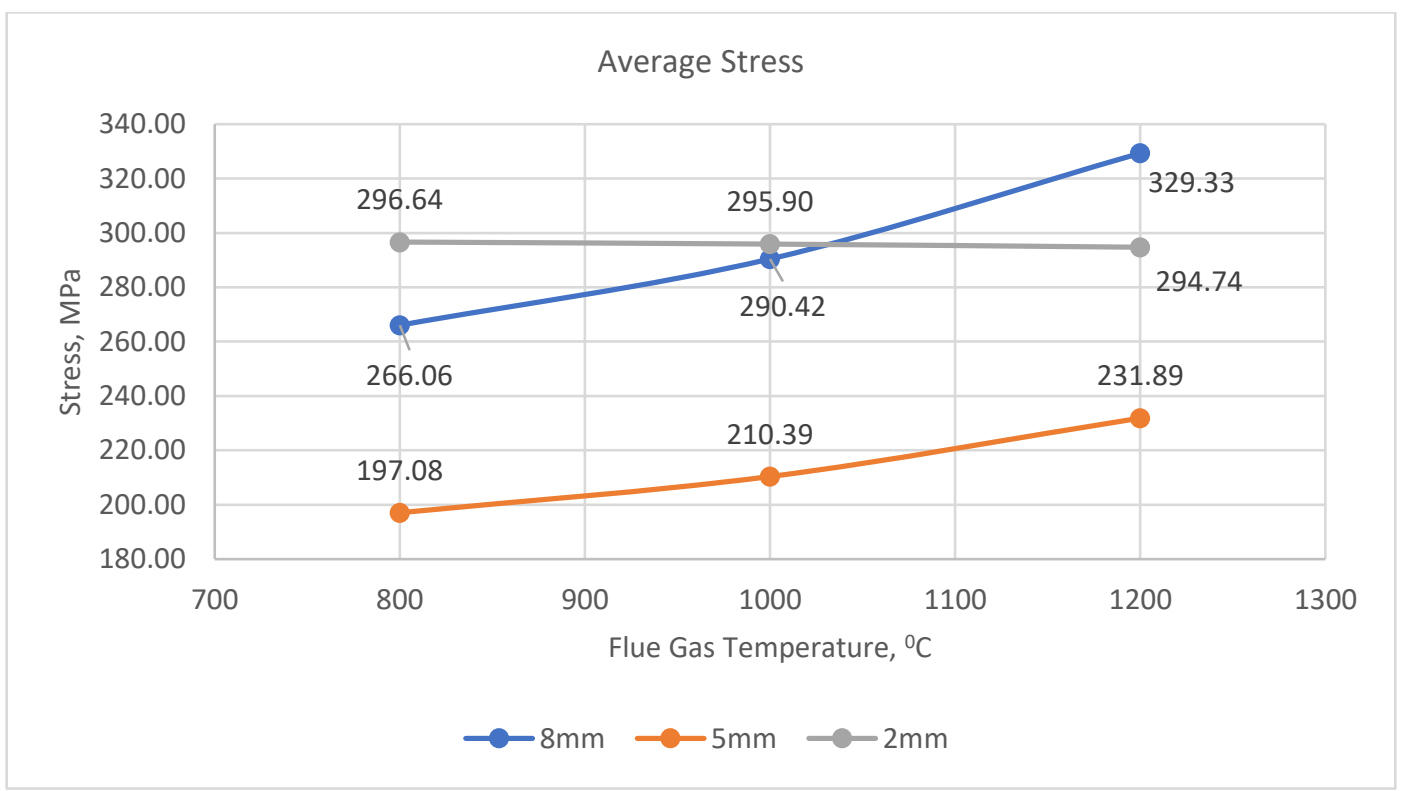

Fig. 13: Average stress along the y-axis on top tube

Published By:

Blue Eyes Intelligence Engineering and Sciences Publication

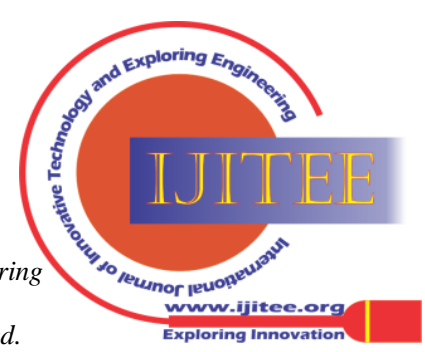




\subsection{Deformation}

Deformation is a change of the dimension of shape of a body due to an applied external force. In this study, 3 variation of flue gas temperature, internal pressure and temperature shall affect the shape of 2-dimensional tube.

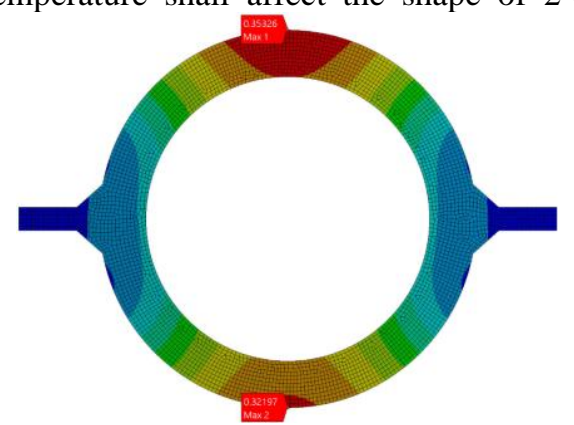

$8 \mathrm{~mm} @ 800^{\circ} \mathrm{C}$

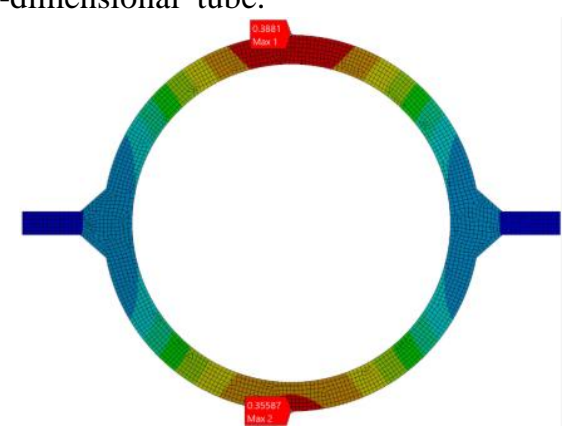

$5 \mathrm{~mm} @ 800^{\circ} \mathrm{C}$

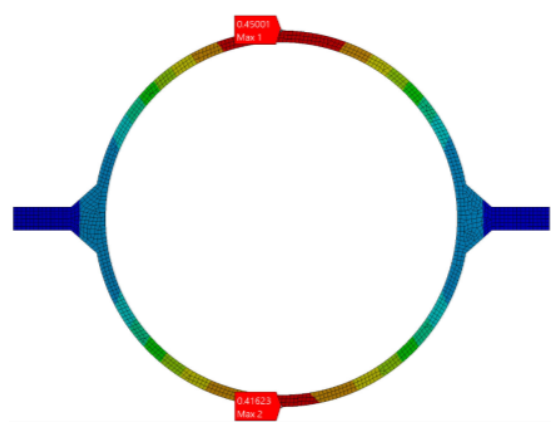

$8 \mathrm{~mm} @ 800^{\circ} \mathrm{C}$

Fig. 14: Deformation at $800^{\circ} \mathrm{C}$

Figure 14 shows the deformation of tubes based on $800^{\circ} \mathrm{C}$ flue gas temperature on the upper part of tube. Observed that the contour of deformation is lower at opposite of upper side due to temperature difference. The maximum deformation recorded at tube wall thickness $2 \mathrm{~mm}$ at $0.45 \mathrm{~mm}$. While $8 \mathrm{~mm}$ and $5 \mathrm{~mm}$ indicates $0.35 \mathrm{~mm}$ and $0.38 \mathrm{~mm}$. Figure 15
Expected the shape of tubes will deformed more when higher temperature applied to the tube. The thickness of tube is another major factor for the deformation process due to temperature.

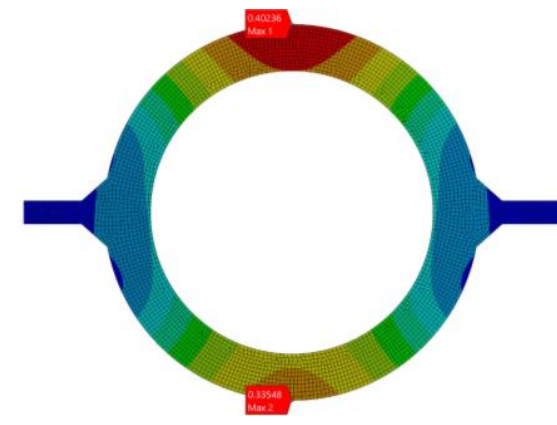

$8 \mathrm{~mm} @ 1000^{\circ} \mathrm{C}$

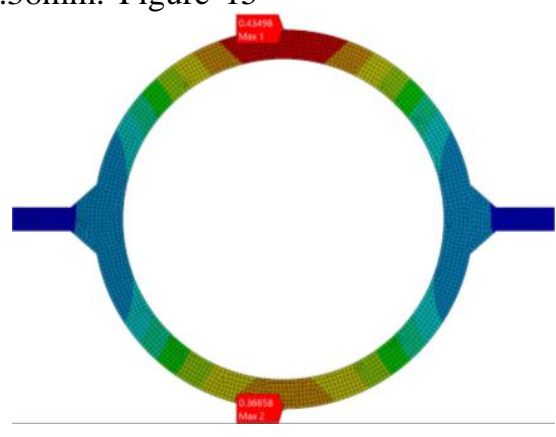

$5 \mathrm{~mm} @ 1000^{\circ} \mathrm{C}$

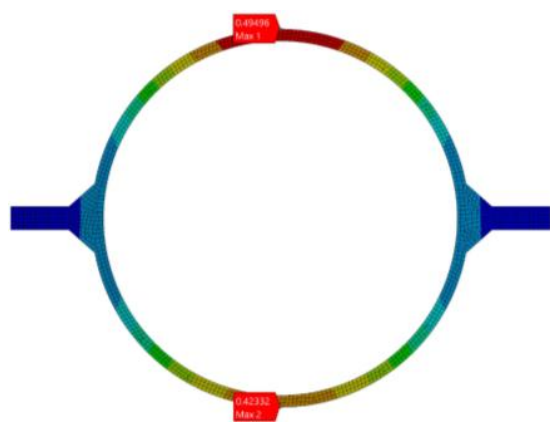

$8 \mathrm{~mm} @ 1000^{\circ} \mathrm{C}$

Fig. 15: Deformation at $1000^{\circ} \mathrm{C}$

The deformation of tubes based on $1200^{\circ} \mathrm{C}$ flue gas temperature on the upper part of tube as shown in Figure 16. The maximum deformation recorded on $2 \mathrm{~mm}$ tube thickness is $0.57 \mathrm{~mm}$. While $8 \mathrm{~mm}$ and $5 \mathrm{~mm}$ indicates deformation at $0.48 \mathrm{~mm}$ and $0.51 \mathrm{~mm}$. Temperature from flue gas and fluid shows the deformation of tubes based on $1000^{\circ} \mathrm{C}$ flue gas temperature on the upper part of tube. The maximum deformation recorded on $2 \mathrm{~mm}$ tube thickness at $0.50 \mathrm{~mm}$. While $8 \mathrm{~mm}$ and $5 \mathrm{~mm}$ indicate measurement at $0.40 \mathrm{~mm}$ and $0.44 \mathrm{~mm}$.

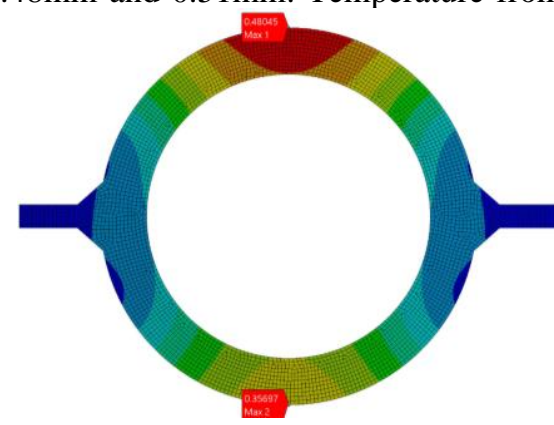

$8 \mathrm{~mm} @ 1200^{\circ} \mathrm{C}$

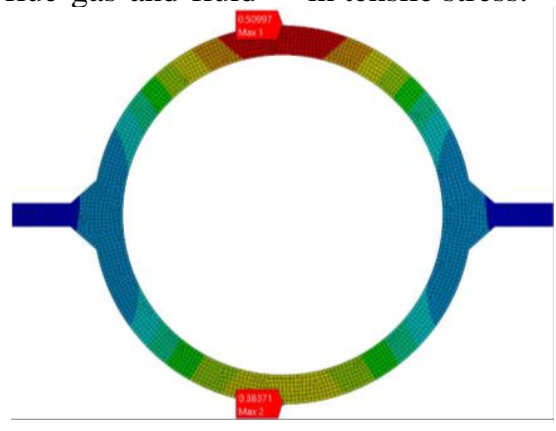

$5 \mathrm{~mm} @ 1200^{\circ} \mathrm{C}$ gave an effect the deformation of tube which higher temperature tend to higher deformation as per shown in Figure 17. It caused the tube to become oval during operation which on $\mathrm{x}$-axis is compressive stress and $\mathrm{y}$-axis is in tensile stress.

Fig. 16: Deformation at $1200^{\circ} \mathrm{C}$

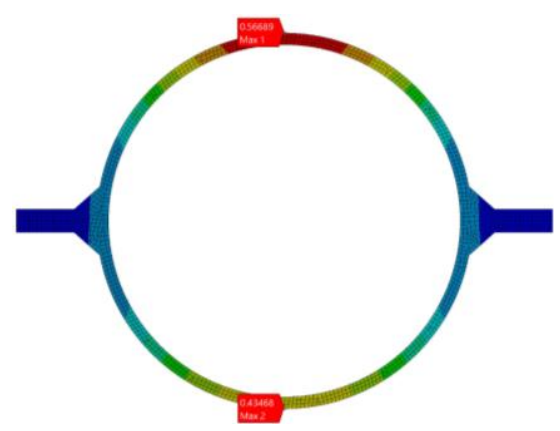

$8 \mathrm{~mm} @ 1200^{\circ} \mathrm{C}$

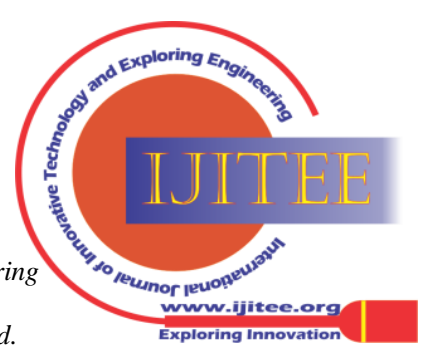




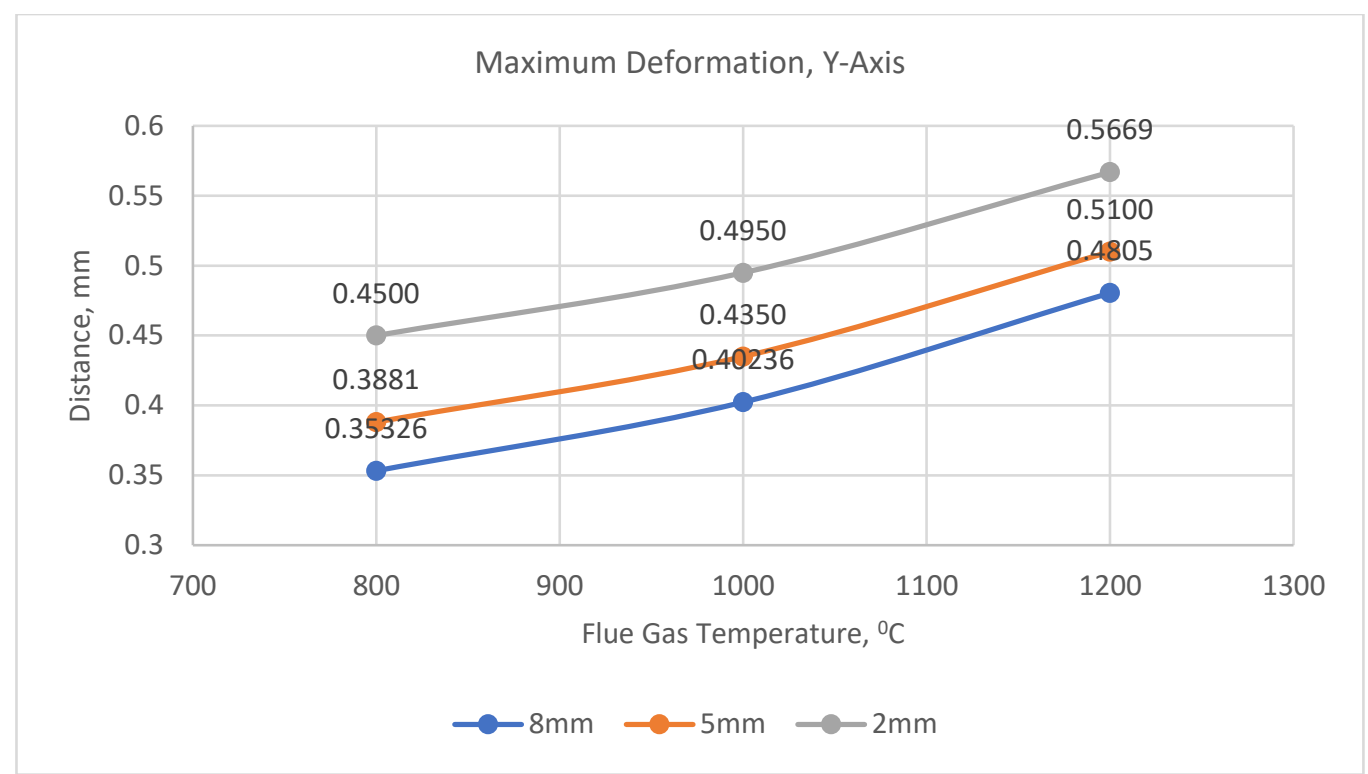

Fig. 17: Maximum deformation

\subsection{Factor of Safety}

Factor of safety in this boiler tube study defined by the ratio of the ultimate strength of a tube to the actual working stress when in use. The minimum safety factor value is depending on the safety rules of a country or organization. Refer to previous study, the minimum safety factor allowable is 4 . Figure 18 shows the FOS for tubes at $800^{\circ} \mathrm{C}$ flue gas temperature applied on upper part of tube. The minimum safety factor indicates that $2 \mathrm{~mm}$ tube is the lowest at 1.1. While $8 \mathrm{~mm}$ and $5 \mathrm{~mm}$ shows 8.9 and 7.3. it is shows that the failures of the $2 \mathrm{~mm}$ is in high priority of concern.

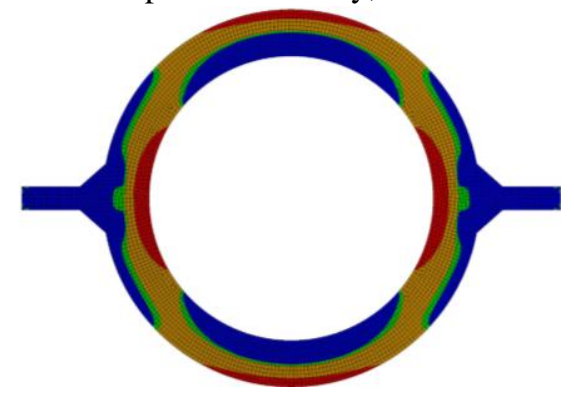

$8 \mathrm{~mm} @ 800^{\circ} \mathrm{C}$

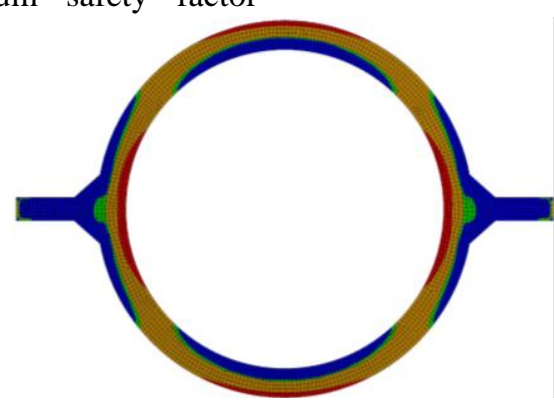

$5 \mathrm{~mm} @ 800^{\circ} \mathrm{C}$

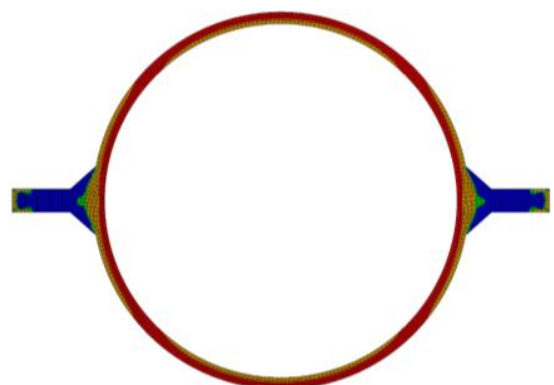

$2 \mathrm{~mm} @ 800^{\circ} \mathrm{C}$

Fig. 18: Safety factor at $800^{\circ} \mathrm{C}$

Figure 19 shows the FOS for tubes at $1000^{\circ} \mathrm{C}$ flue gas temperature on the upper part of tubes. Same the minimum safety factor still at $2 \mathrm{~mm}$ wall thickness tube. While $8 \mathrm{~mm}$ and $5 \mathrm{~mm}$ is 8.8 and 7.83 . Observed that the $5 \mathrm{~mm}$ tubes indicate increasing of safety factor by increasing temperature. Probability the optimum thickness for the boiler tube at this parameter set up give an effect to the safety factor.

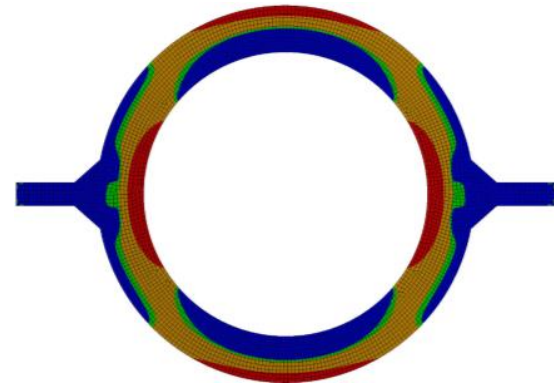

8mm@1000 C

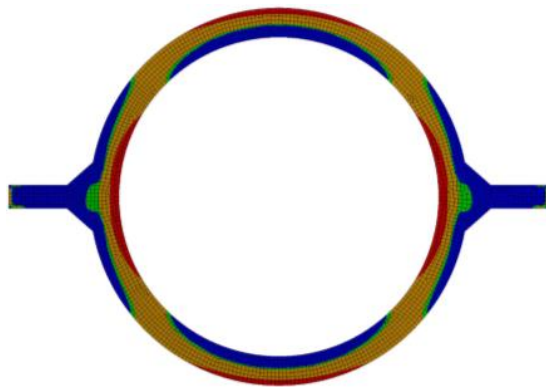

$5 \mathrm{~mm} @ 1000^{\circ} \mathrm{C}$

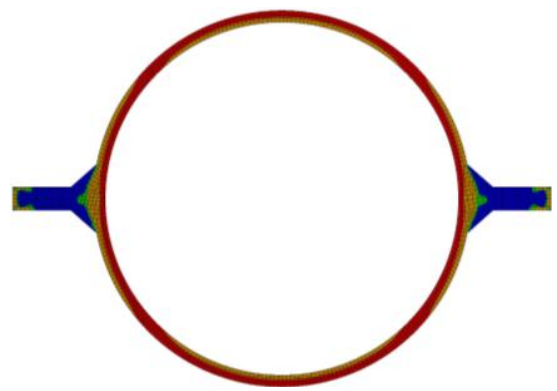

2mm@1000 C

Fig. 19: Safety factor at $1000^{\circ} \mathrm{C}$

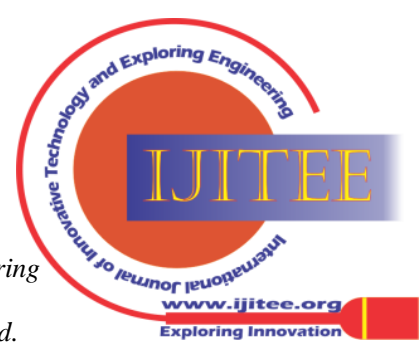


Figure 20 shows the FOS for tubes at $1200^{\circ} \mathrm{C}$ flue gas to changes of shutdown of boiler in a sudden. The safety temperature on the upper part of tubes. The minimum safety factor deteriorated by decreasing of wall thickness and high factor still holds by $2 \mathrm{~mm}$ wall thickness at 1.217 . While $8 \mathrm{~mm}$ temperature as shown in Figure 21 . Therefore, the monitoring and $5 \mathrm{~mm}$ is 8.8 and 8.0 . observed $5 \mathrm{~mm}$ and $2 \mathrm{~mm}$ shows an of the thickness tube is the main priority for the maintenance increasing of safety factor by increase the temperature. of the boiler to achieve better efficiency and longer operation However, tube $2 \mathrm{~mm}$ is not safe under operating of boiler due without predictable shutdown.

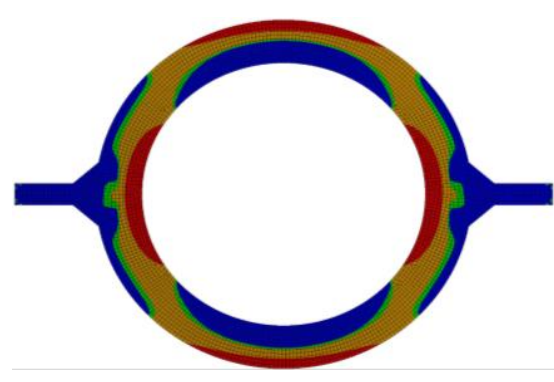

$8 \mathrm{~mm} @ 1200^{\circ} \mathrm{C}$

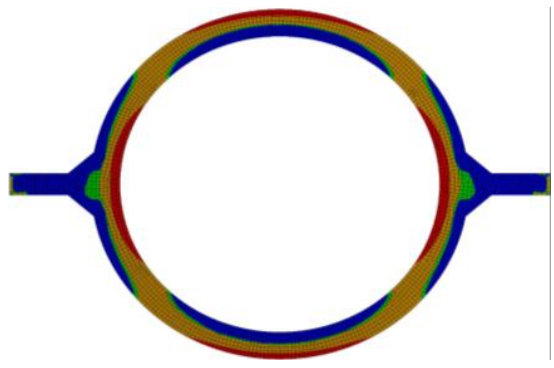

$5 \mathrm{~mm} @ 1200^{\circ} \mathrm{C}$

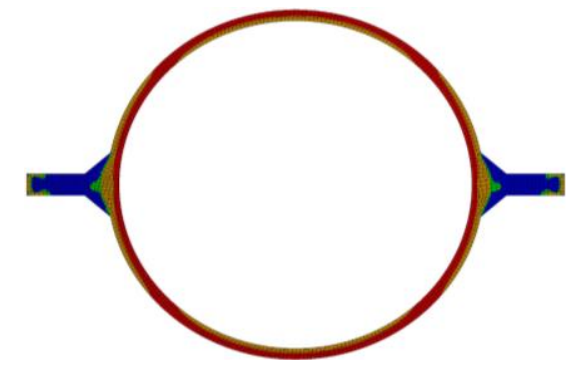

$2 \mathrm{~mm} @ 1200^{\circ} \mathrm{C}$

Fig. 20: Safety factor at $1200^{\circ} \mathrm{C}$

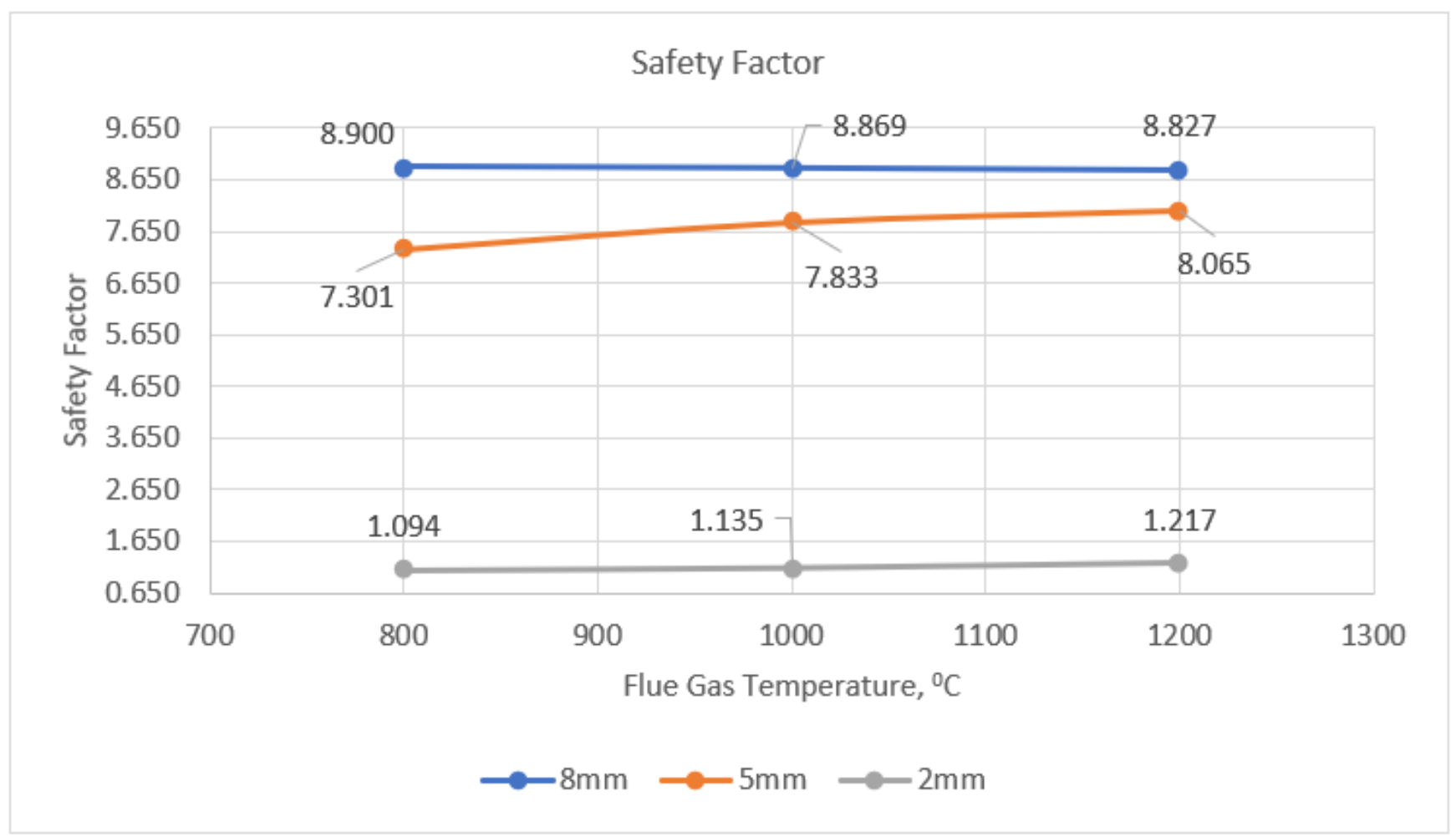

Fig. 21: Safety factor along y-axis on top tube

\subsection{Operating Hoop stress}

Hoop stress is the stress that occurs along the circumference of rotationally symmetric object such as pipe or tube when pressure is applied. The hoop stress is twice of longitudinal stresses and hence is of utmost importance. The hoop stress developed in the tube is caused by internal pressure and can be estimated by formula below:

$$
\sigma_{h}=\frac{P d}{2 t}
$$

where $\mathrm{P}$ is operational internal pressure, $\mathrm{d}$ is inside diameter and $t$ is the thickness of tube.

Refer to operating hoop stress chart, tube thickness $2 \mathrm{~mm}$ is exceeding the maximum allowable stress and it is indicating that the tube would have potential failure. The cause of erosion or wall thinning to the tube is possible for the tube tearing apart.

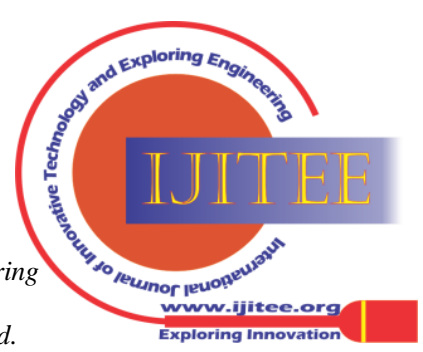




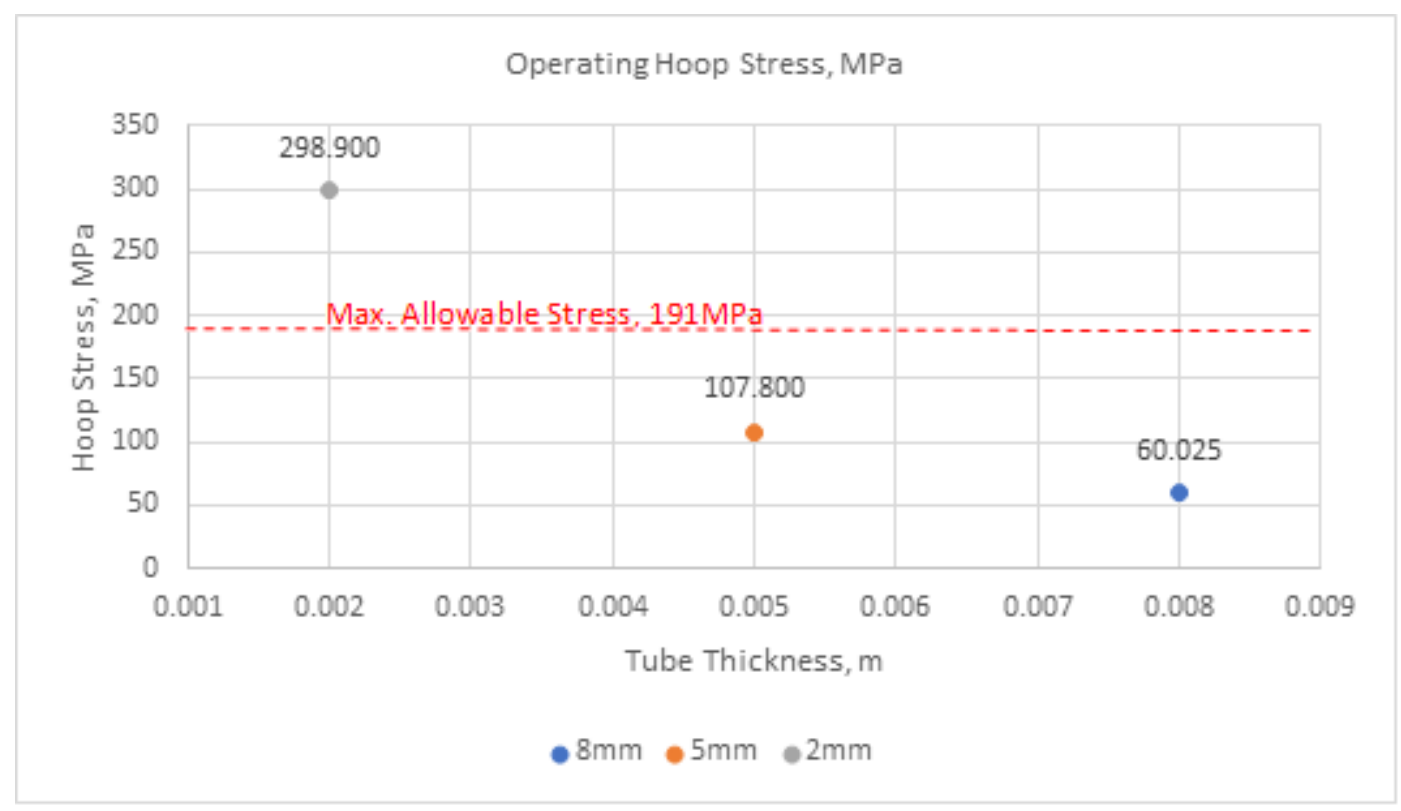

Fig. 22: Hoop stress chart

\section{CONCLUSION}

The 2D boiler water wall tube simulated in Ansys thermal steady-state and static structural tendency to failure on fire-face side due to heat exposed. This study shows that that potential failure mechanism occurs due to the wall thinning of the top of the tube at the side which faces the fire and exposed to high temperature. A scheduled maintenance of the boiler tube and regular inspection of the wall thickness is a top priority requirement.

\section{REFERENCES}

1. ASME. (2018, 05 12). Mechanical Properties for SA-210 Grade C. Retrieved from Tota Materia:

https://www.totalmateria.com/page.aspx?ID=Home\&LN=EN

2. Basu, P., Kefa, C., \& Jestin, L. (2000). Boilers and Burners Design and Theory. New York: Springer-Verlag

3. Convective Heat Transfer. (2018, 05 13). Retrieved from Engineering Tool Box: https://www.engineeringtoolbox.com/convective-heattransfer-d 430.html

4. Dhua, S. (2010). Metallurgical investigation of failed boiler waterwall tubes received from a thermal power station. Engineering Failure Analysis, 17, 1572-1579.

5. Factors of Safety. (2018, 05 13). Retrieved from Engineering Tool Box: https://www.engineeringtoolbox.com/factors-safety-fosd_1624.html

6. Sarkar, D. K. (2015). Thermal Power Plant Design and Operation Amsterdam: Joe Hayton.

7. ASTM. (2015). Standard Specification for Seamless Medium-Carbon Steel Boiler and Superheater. Astm, 01(Reapproved), 3-5.

8. Kalu, I. E., Inglis, H. M., \& Kok, S. (2020). Failure assessment methodology for boiler tubes with localized external erosion defects. International Journal of Pressure Vessels and Piping, 188(August), 104190. https://doi.org/10.1016/j.ijpvp.2020.104190

9. $\quad$ Pang, L., Yi, S., Duan, L., Li, W., \& Yang, Y. (2019). Thermal Stress and Cyclic Stress Analysis of a Vertical Water-Cooled Wall at a Utility Boiler. https://doi.org/10.3390/en12061170

10. Chinsuwan, A., \& Dutta, A. (2009). An investigation of the heat transfer behavior of longitudinal finned membrane water wall tubes in circulating fluidized bed boilers. Powder Technology, 193(2), 187194. https://doi.org/10.1016/j.powtec.2009.03.023

11. Liu, S. W., Wang, W. Z., \& Liu, C. J. (2017). Failure analysis of the boiler water-wall tube. Case Studies in Engineering Failure Analysis, 9(May), 35-39. https://doi.org/10.1016/j.csefa.2017.06.002

2. Hosseini, R. K., \& Yareiee, S. (2019). Failure analysis of boiler tube at a petrochemical plant. Engineering Failure Analysis, 106(February)

104146

https://doi.org/10.1016/j.engfailanal.2019.104146

13. Duarte, C. A., Espejo, E., \& Martinez, J. C. (2017). Failure analysis of the wall tubes of a water-tube boiler. Engineering Failure Analysis, 79(May), 704-713. https://doi.org/10.1016/j.engfailanal.2017.05.032

\section{AUTHORS PROFILE}

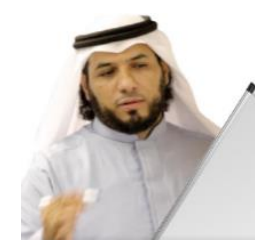

Dr. Asiri's, research activities are on the vibration control of mechanical systems. He and his advisor, Prof. A. Baz, have innovated a new class of support struts called periodic struts as an isolator of the mechanical vibrations. He presented the innovative use of unique characteristics of periodic struts in many critical applications where the control of the wave propagation and the force transmission both in the spectral and spatial domains is essential to stopping/confining the propagation of undesirable disturbances. He got in 2010 a patent from KACST titled: Differential Agitator and a patent from US Patents titled: Smart Boat for Swimming Pool Maintenance and Water Safety. Dr. Asiri currently teaches vibrations and control courses for undergraduate and graduate students. In addition, he published lately many papers on vibration analysis and modal analysis of Functionally Graded Materials using FEM.
Published By: Blue Eyes Intelligence Engineering and Sciences Publication 